\title{
Achados clínicos, laboratoriais e anatomopatológicos em bovinos com febre catarral maligna
}

Tatiane Vitor da Silva ${ }^{[a]}$, Laís Resende Paulino ${ }^{[a]}$, José Augusto Bastos Afonso ${ }^{[b]}$, Carla Lopes de Mendonça $a^{[b]}$, Nivaldo de Azevedo Costa ${ }^{[b]}$, Nivan Antônio Alves da Silva $a^{[b]}$, Rodolfo José Cavalcanti Souto ${ }^{[b]}$, Luiz Teles Coutinho[ ${ }^{[b]}$, José Cláudio de Almeida Souza ${ }^{[a]}$, Jobson Filipe de Paula Cajueiro[b]

\footnotetext{
[a] Programa de Residência em Sanidade de Ruminantes, Clínica de Bovinos, Universidade Federal Rural de Pernambuco (UFRPE), Garanhuns, PE, Brasil

[b] Clínica de Bovinos, Universidade Federal Rural de Pernambuco (UFRPE), Garanhuns, PE, Brasil
}

*Autor correspondente

e-mail: ta_ty_vitor@hotmail.com

\section{Resumo}

Afebre catarral maligna (FCM) é uma doença infecciosa, viral e cosmopolita que afeta bovinos e outras espécies de ruminantes. Possui caráter agudo com baixa morbidade, alta mortalidade e geralmente acomete animais jovens entre 1 e 4 anos de idade. São conhecidas duas formas geográficas e epidemiologicamente distintas da enfermidade: a associada à gnus (forma africana) e a associada a ovinos (forma americana). 0 objetivo deste trabalho é relatar os achados clínicos, laboratoriais e anatomopatológicos de três bovinos acometidos com FCM, oriundos de municípios do Estado de Pernambuco e atendidos na Clínica de Bovinos, Campus Garanhuns, Universidade Federal Rural de Pernambuco (CBG/UFRPE) no ano de 2016. As informações foram resgatadas das fichas de acompanhamento clínico. Foram acometidas três vacas leiteiras, com idade entre 4 e 8anos. Na anamnese, os proprietários se queixaram que os animais apresentavam opacidade de córnea, cegueira e secreção nasal, e em dois casos havia contato com ovinos. Os sinais clínicos incluíam febre, apatia, linfadenopatia, opacidade de córnea, diminuição do reflexo de ameaça, epífora, edema de pálpebras, secreção ocular mucosa, além de sialorreia, falta de apetite e hipomotilidade ruminal. Os sinais clínicos observados foram característicos da doença. No hemograma, verificaram-se respostas inflamatórias variadas: um animal apresentou leucopenia com linfopenia; outro, hiperfibrinogenemia e desvio à esquerda regenerativo; e o terceiro, hiperfibrinogenemia, linfopenia e inversão da proporção linfócitos/segmentados. A diversificação na série branca observada neste trabalho pode estar relaciona à severidade e estágio da doença, bem como à capacidade individual de resposta. Todos os animais tiveram evolução superaguda da doença, vindo a óbito um dia após o internamento. De acordo com a literatura, a duração do curso clínico da doença aguda é de 3 a 7 dias e nos casos superagudos os animais podem morrer dentro de um a dois dias. 
Na necropsia, os vasos das leptomeninges estavam congestos; no TGI foram encontradas lesões variando desde hiperemia da mucosa até úlceras de diferentes diâmetros, além de hemorragias petequiais e sulfusões e linfonodos mesentéricos aumentados. No exame histopatológico, as lesões observadas foram vasculite com acúmulo de células mononucleares na adventícia e necrose fibrinóide das paredes vasculares, além de infiltração mononuclear em vários órgãos, o que permitiu fechar o diagnóstico de FCM. A FCM deve ser incluída no diagnóstico diferencial de doenças neurológicas e ulcerativas nas mucosas e a coabitação entre bovinos e ovinos deve ser evitada, visto que estes podem ser fontes de infecção do herpesvírus ovino tipo 2. 